\title{
Aplikasi Pencarian Dokter di Kota Padang Berbasis Mobile
}

\author{
Yance Sonatha ${ }^{[1]^{*}}$, Ervan Asri ${ }^{[2]}$, Indri Rahmayuni ${ }^{[3]}$ \\ Jurusan Teknologi Informasi Politeknik Negeri Padang ${ }^{[1], ~[2], ~[3] ~}$ \\ Limau Manis Padang, Sumatera Barat \\ sonatha.yance@gmail.com ${ }^{[1]}$,ervanasri@gmail.com ${ }^{[2]}$,rahmayuni@gmail.com ${ }^{[3]}$
}

\begin{abstract}
Nowadays people have started to realize the importance of health. Everyone wants to quickly find out where the right doctor is if they want to get health services or have shown certain symptoms of illness. This research resulted in an application called "find doctor" which aims to be able to find the location and information of the doctor closest to the user while in the city of Padang. This study adopted stages of the Waterfall Model and was built using the Location Based Service method provided by Android. This application is built from two sides, namely the android client and the web server. This research produces an application that can find the location and information of the desired doctor's practice in the city of Padang. Applications that can be accessed using an internet browser (server) and android smartphone (client) with a minimum Android 5.0 operating system.
\end{abstract}

Keywords- android, find doctor, location based service, Padang, Waterfall Model

\footnotetext{
Abstrak - Saat ini masyarakat sudah mulai menyadari akan pentingnya kesehatan. Semua orang menginginkan dengan cepat mengetahui keberadaan dokter yang tepat apabila mereka ingin mendapatkan layanan kesehatan ataupun telah memperlihatkan gejala sakit tertentu. Penelitian ini menghasilkan sebuah aplikasi yang dinamakan "find doctor" yang bertujuan untuk dapat menemukan lokasi dan informasi dokter yang terdekat dengan pengguna selama berada di Kota Padang. Penelitian ini mengadopsi tahapan Model Waterfall dan dibangun menggunakan metode Location Based Service yang disediakan oleh android. Aplikasi ini dibangun dari dua sisi yaitu client android dan server web. Penelitian ini menghasilkan sebuah aplikasi yang dapat menemukan lokasi dan informasi praktek dokter yang diinginkan di Kota Padang. . Aplikasi ini dapat diakses menggunakan browser internet (server) dan smartphone android (client) dengan minimum sistem operasi Android 5.0.
}

Kata Kunci-android, find doctor, location based service, Padang, Model Waterfall

\section{PENDAHULUAN}

Kesehatan merupakan salah satu kebutuhan utama masyarakat. Ketika seseorang mengalami gejala penyakit, harus segera dicari solusi untuk mengobatinya. Salah satunya dengan mencari dokter yang tepat sesuai dengan penyakit yang diderita. Ada beragam klasifikasi dokter mulai dari dokter umum sampai dokter spesialis. Sesuai namanya, dokter spesialis merupakan dokter yang memiliki spesialisasi terhadap suatu bidang atau bagian tubuh tertentu. Di Indonesia sendiri, terdapat beragam spesialisasi dokter, termasuk di Kota Padang yang akan menjadi objek penelitian kali ini.

Berdasarkan informasi dari Badan PPSDM Kesehatan Kementerian Kesehatan Republik Indonesia, terdapat 34 rumah sakit di Kota Padang, yang meliputi rumah sakit umum, khusus, kejiwaan baik yang dimiliki pemerintah maupun pihak swasta. Dari 34 rumah sakit tersebut terdapat 4831 sumber daya manusia bidang kesehatan. Dari 4831 tersebut terdapat 292 dokter umum, 57 dokter gigi, 590 dokter spesialis dan selebihnya merupakan tenaga kesehatan lainnya yang terdiri dari perawat, bidan, ahli farmasi, ahli gizi, ahli kesehatan masyarakat, ahli kesehatan lingkungan, ahli terapi fisik, teknisi medik dan teknisi biomedik [1].

Sementara itu, perkembangan teknologi Informasi terutama penggunaan smartphone di Indonesia semakin meningkat. Berdasarkan perhitungan data pada tahun 2020 terdapat sekitar 191.6 juta pengguna smartphone di Indonesia (statista, 2021). Jika dibandingkan dengan jumlah penduduk Indonesia berdasarkan sensus penduduk 2020 yakni 270.20 juta jiwa (bps,2021), maka hampir 71\% penduduk adalah pengguna smartphone. Saat ini, Indonesia merupakan pangsa pasar smartphone keempat terbesar di dunia setelah Tiongkok, India dan Amerika Serikat. Gambar 1 berikut memperlihatkan jumlah pengguna smartphone di Indonesia dari tahun 2015 - 2020 dan proyeksi pengguna sampai tahun 2025 . 


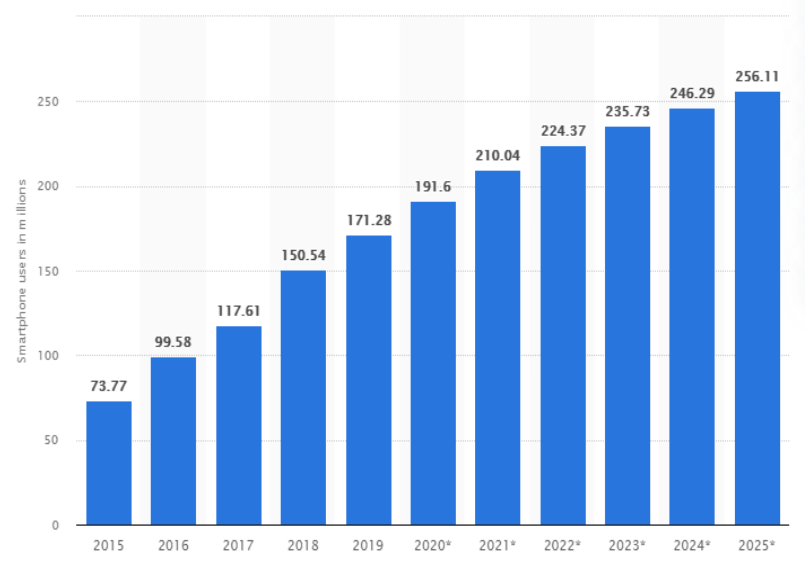

Gambar 1. Jumlah Pengguna Smartphone di Indonesia 20152025 [2]

Penelitian ini bertujuan untuk mengembangkan sebuah aplikasi yang menyediakan informasi keberadaan dokter-dokter di Kota Padang, meliputi jadwal dan lokasi praktik serta petunjuk arah menuju lokasi.

\section{TINJAUAN PUSTAKA}

\section{A. Sistem Infomasi Geografis (SIG)}

Sistem Informasi Geografis (SIG) merupakan sebuah sistem informasi khusus yang mengolah data dengan informasi yang bereferensi keruangan (data spasial). Ini berarti SIG memiliki kemampuan untuk membangun, menyimpan, mengelola dan menampilkan informasi bereferensi geografis, misalnya data yang diidentifikasi menurut lokasinya, dalam sebuah basis data[3]. Teknologi GIS menggunakan informasi digital yang didapatkan dari metode pembuatan data digital[4]. SIG merupakan sistem kompleks yang umumnya terintegrasi dengan sistem komputer lainnya di tingkat fungsional dan jaringan[5].

\section{B. Location Based Service(LBS)}

LBS adalah layanan informasi yang dapat diakses dengan perangkat seluler melalui jaringan seluler dan memanfaatkan kemampuan untuk memanfaatkan lokasi perangkat seluler [6]. Gambar 2 berikut memperlihatkan kaitan antara Sistem Informasi Geografis dengan LBS.

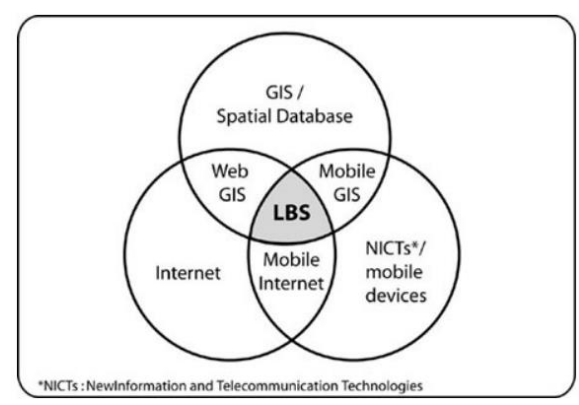

Gambar 2. Hubungan antara SIG dengan LBS
Gambar 2 menunjukkan bahwa antara GIS dan LBS memiliki beberapa kesamaan tertentu yang secara umum menangani data dengan referensi posisi dan fungsi analisis spasial. Sistem Informasi Geografis telah dikembangkan selama beberapa dekade terakhir, sedangkan LBS baru muncul setelah adanya evolusi layanan seluler publik. Sehubungan dengan kelompok pengguna, SIG dapat dilihat sebagai sistem "profesional" yang masih tradisional yang ditujukan untuk pengguna berpengalaman dengan koleksi fungsionalitas yang luas. . Sebaliknya, LBS dikembangkan sebagai layanan terbatas untuk kelompok pengguna non-profesional yang lebih besar. Aplikasi LBS semacam itu beroperasi dengan batasan seluler lingkungan komputasi seperti daya komputasi rendah, tampilan kecil, atau waktu pengoperasian baterai telepon seluler [6].

\section{Global Positioning System (GPS)}

GPS atau Global Positioning System, merupakan sebuah alat atau sistem yang dapat digunakan untuk menginformasikan penggunanya dimana lokasinya berada (secara global) di permukaan bumi yang berbasiskan satelit[7]. Data dikirim dari satelit berupa sinyal radio dengan data digital. Dimanapun pengguna tersebut berada, maka GPS bisa membantu menunjukan arah. Layanan GPS ini tersedia gratis[8].

Awalnya GPS hanya digunakan hanya untuk kepentingan militer, tapi pada tahun 1980-an dapat digunakan untuk kepentingan sipil. GPS dapat digunakan dimanapun juga dalam 24 jam. Posisi unit GPS akan ditentukan berdasarkan titik-titik koordinat latitude dan longitude[9].

\section{Google Map Service}

Terdapat banyak tools yang dapat digunakan untuk mengimplementasikan SIG. Salah satu tools berbasis website yang sudah disediakan oleh google dengan layanan Open Source yaitu google Maps. Google Maps API merupakan perkembangan dari google Maps yang memungkinkan untuk menggunakan google Maps di dalam website[10].

\section{METODOLOGI}

Penelitian ini bertujuan untuk menghasilkan sebuah aplikasi yang dapat menyediakan informasi keberadaan dokter terdekat dari posisi user. Untuk mengembangkan aplikasi ini diadopsi dari tahapan Waterfall Model. Tahapan model waterfall tersebut adalah analisis kebutuhan, perancangan, konstruksi serta implementasi dan pengujian [11-12].

Gambar 3 berikut memperlihatkan model waterfall yang digunakan dalam penyelesaian penelitian ini[13]. 


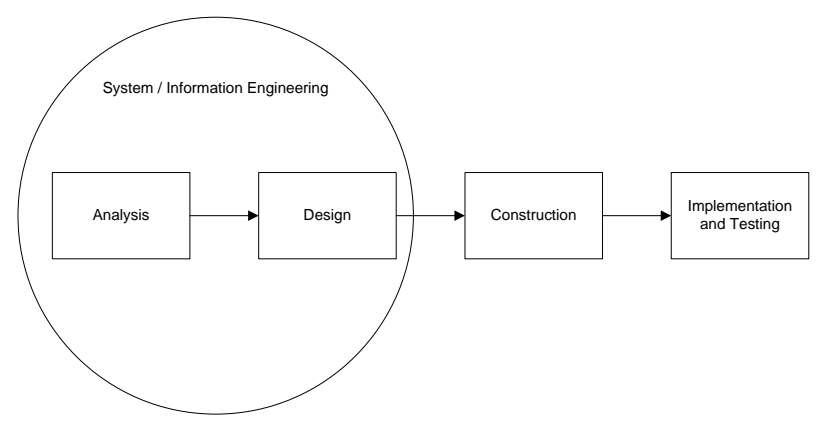

Gambar 3. Model Waterfall

1) Analisis Kebutuhan

Pada tahap ini pengembang sistem membutuhkan komunikasi yang bertujuan memahami perangkat lunak yang diharapkan oleh pengguna dan keterbatasan perangkat lunak tersebut. Informasi ini biasanya dapat diperoleh melalui wawancara, diskusi atau survei langsung

2) Perancangan

Tahapan ini mencakup kepentingan desain teknis seperti bahasa pemrograman, lapisan data, layanan, dan sebagainya. Spesifikasi desain biasanya akan dibuat untuk menguraikan bagaimana logika bisnis yang tercakup dalam analisis akan diimplementasikan secara teknis.

3) Konstruksi

Hasil desain dari tahap sebelumnya dikonversi menjadi kode pemrograman

4) Implementasi dan Pengujian

Aplikasi siap pakai diuji dengan menggunakan data nyata, dan diimplementasikan dari kedua sisi (client dan server).

\section{HASIL DAN PEMBAHASAN}

\section{A. Analisis Kebutuhan}

Suatu aplikasi dapat berjalan dengan optimal apabila pengguna memiliki kemampuan untuk menjalankan aplikasi tersebut. Kebutuhan pada Aplikasi Pencarian Praktik Dokter Spesialis Di Kota Padang adalah sebagai berikut:

- Aplikasi ini membantu pengguna mengetahui informasi mengenai praktik dokter spesialis di Kota Padang seperti daftar keseluruhan praktik dokter, spesialisasi dokter, jadwal praktik serta lokasi keberadaan praktik dokter.

- Aplikasi ini membantu mencari lokasi dari praktik dokter spesialis, agar pengguna dapat langsung menemukan lokasi praktik sesuai dengan kebutuhan. Lokasi tersebut didapati karena aplikasi ini dilengkapi dengan fungsi google maps.

\section{B. Perancangan}

1) Diagram Konteks Aplikasi

Diagram konteks pada 4 menggambarkan siklus sistem aplikasi pencarian praktik dokter di Kota Padang secara keseluruhan mulai dari input ke sistem hingga output dari sistem. Pada diagram ini terdapat dua entitas yaitu admin dokter dan user. Admin dokter bertugas mengelola data untuk dimasukkan kedalam sistem. User hanya memiliki akses untuk melihat informasi mengenai praktik dokter spesialis.

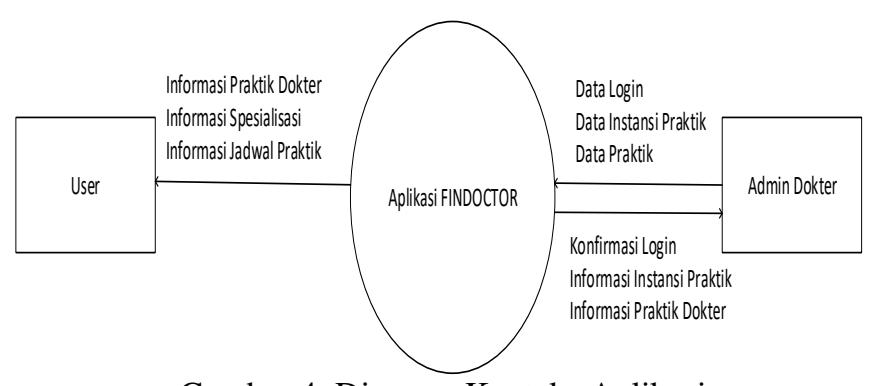

Gambar 4. Diagram Konteks Aplikasi

2) Rancangan Struktur Menu

a. Sisi Aplikasi (Client)

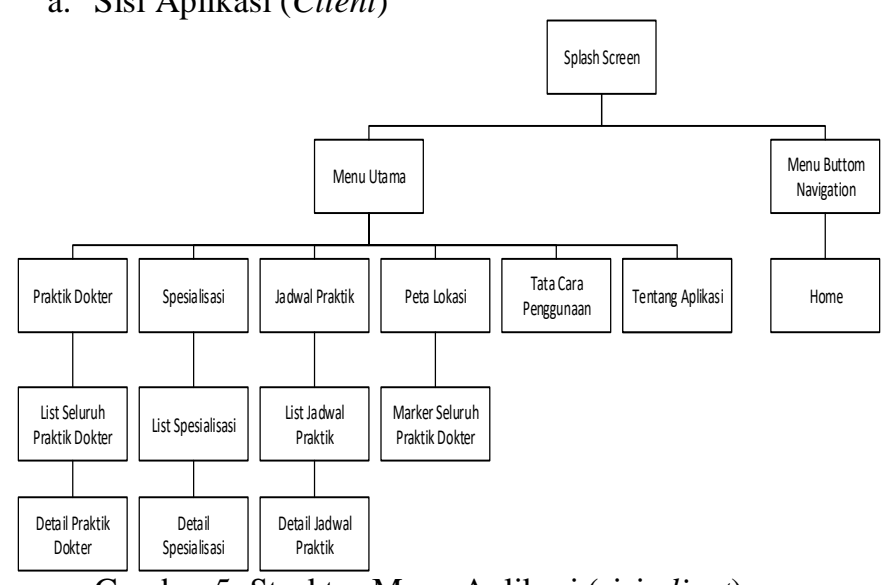

Gambar 5. Struktur Menu Aplikasi (sisi client)

Dari struktur menu aplikasi pada Gambar 5 terdapat enam pilihan pada menu utama dan satu pilihan pada menu buttom navigation. Menu utama terdiri dari menu praktik dokter, spesialisasi, jadwal praktik, peta lokasi, tata cara penggunaan dan tentang aplikasi yang ditujukan untuk pengguna aplikasi. Pada menu praktik dokter terdapat list keseluruhan praktik dokter dan detail masing-masing praktik dokter, pada spesialisasi terdapat list spesialisasi dan detail masing-masing spesialisasi, pada menu jadwal praktik terdapat list jadwal praktik dan detail masing-masing jadwal praktik, serta pada menu peta lokasi terdapat marker dari seluruh praktik dokter. Menu buttom navigation terdiri dari menu home yang berguna untuk kembali ke halaman awal setelah mengakses sub menu lainnya. 


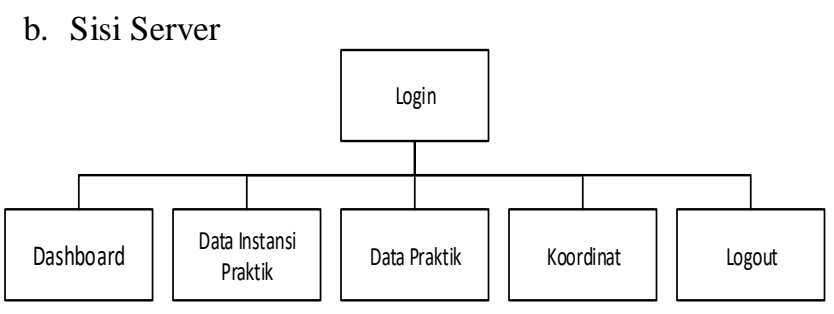

Gambar 6. Struktur Menu Server

Dari struktur menu server pada Gambar 6 terdapat empat pilihan yaitu dasboard, data instansi praktik, data praktik, koordinat dan logout. Pengelolaan data dapat berupa melihat data, menambah data, mengubah data dan menghapus data.

\section{Konstruksi}

Pengembangan sistem didasarkan pada desain yang ada sebelumnya, dengan spesifikasi perangkat lunak yang dibutuhkan :

1) Perangkat lunak untuk pengembangan server: netbeans 8.2, xampp server

2) Perangkat lunak untuk pengembangan client: Android SDK, Android Studio

3) Perangkat lunak untuk implementasi sistem: smartphone android 5.0 minimum

\section{Implementasi dan Pengujian}

Aplikasi ini dikembangkan dari dua sisi yakni sisi client dan server. Dari sisi client alah pengguna smartphone android, dan dari sisi server adalah admin web.

1. Implementasi User Android

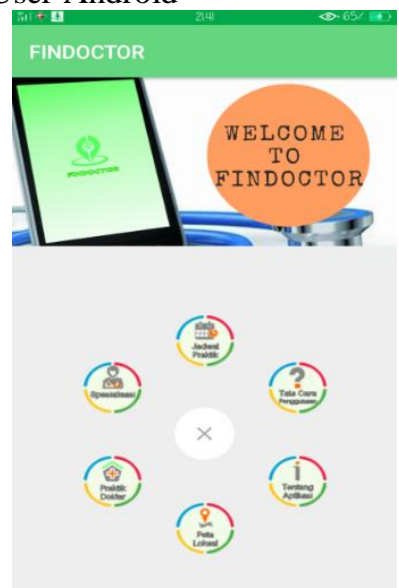

Gambar 7. Tampilan Utama User Android

Pada saat aplikasi dijalankan, maka akan muncul splash screen. Splash Screen merupakan tampilan awal ketika aplikasi pertama kali dijalankan dan akan memakan waktu sekitar 3 detik.

Home merupakan tampilan halaman utama android. Pada halaman utama ini user akan melihat slider gambar, sebuah circle menu dan button navigation. Ketika circle menu dipilih maka akan muncul 6 pilihan menu diantaranya menu praktik dokter, spesialisasi, jadwal praktik, peta lokasi, tata cara penggunaan dan tentang aplikasi seperti terlihat pada Gambar 7.

Setiap menu pada halaman utama ini akan menampilkan detil informasi sesuai dengan penamaan menu tersebut, misalkan menu praktik dokter yang menampilkan daftar seluruh praktik dokter spesialis yang ada di Kota Padang. Tampilan awal akan menampilkan foto praktik dokter, nama dokter serta spesialisasi dokter, seperti terlihat pada Gambar 8 dan rinciannya terlihat pada Gambar 9 berikut :

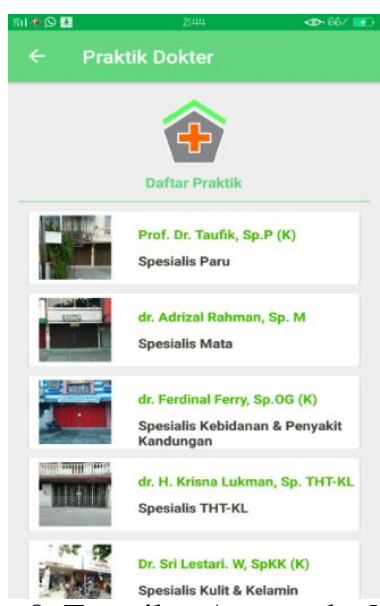

Gambar 8. Tampilan Antarmuka Menu Praktik Dokter

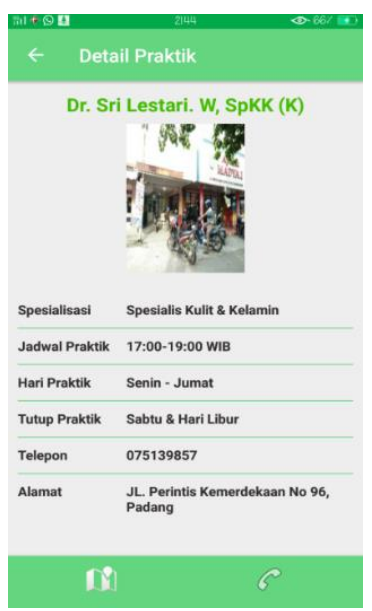

Gambar 9. Tampilan Detail Praktik Dokter

Selain pencarian dokter berdasarkan nama, aplikasi juga dilengkapi fasilitas pencarian dokter berdasarkan jenis spesialisasi penyakit yang ditanganinya. Ini bertujuan untuk lebih memudahkan user dalam mencari dokter yang tepat sesuai dengan penyakit yang diderita.

Menu peta lokasi akan menampilkan titik lokasi seluruh praktik dokter spesialis yang ada di Kota Padang. Ketika salah satu titik lokasi tersebut dipilih, maka akan muncul informasi tentang praktik dokter spesialis tersebut serta dapat melakukan tracking dengan Google Maps. Berikut tampilan menu peta lokasi yang dapat dilihat pada Gambar 10 berikut : 


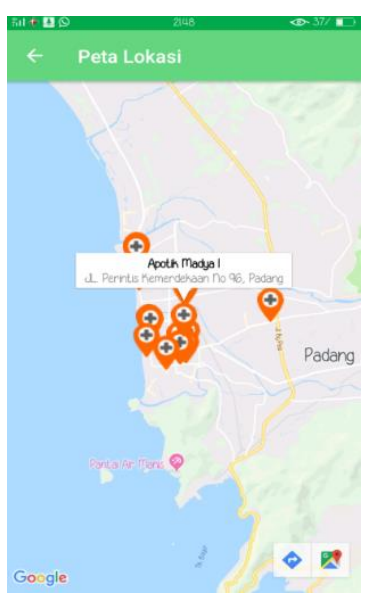

Gambar 10. Tampilan Menu Peta Lokasi

2. Implementasi Server Web

Halaman awal server web mengharuskan user untuk memasukkan username dan password untuk dapat mengakses sistem. Setelah proses validasi, maka akan tampil halaman utama seperti terlihat pada Gambar 11 berikut :

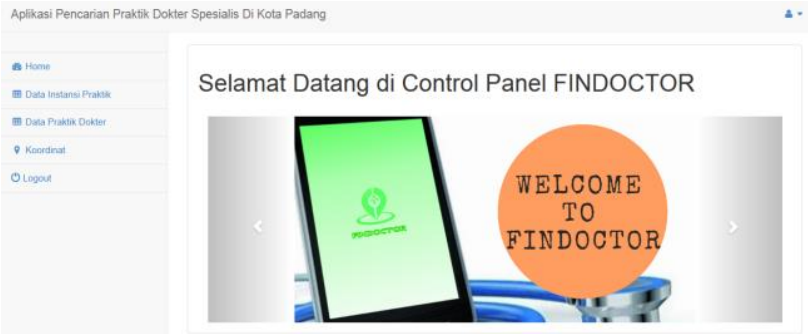

Gambar 11. Tampilan Halaman Utama Server Web

Admin dapat mengelola data instansi praktik berupa menambah, mengubah, menghapus dan melihat data instansi praktik. Data pada instansi praktik terdiri id instansi, nama instansi, alamat, latitude, longitude, telepon dan foto. Berikut tampilan user interface menu data instansi praktik pada level admin yang dapat dilihat pada Gambar 12 berikut

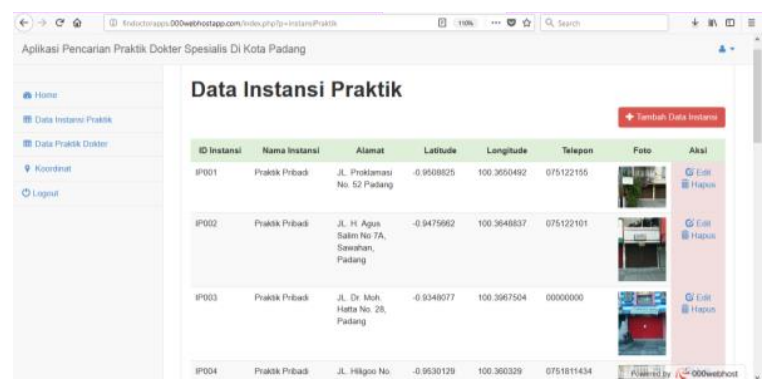

Gambar 12. Interface Data Instansi Praktek

Selain itu admin juga dapat mengelola data praktik dokter yang terdiri dari id praktik, id admin, id instansi, nama dokter, spesialisasi, jadwal praktik, keterangan jadwal, hari praktik dan tutup praktik,seperti tampilan Gambar 13 berikut:

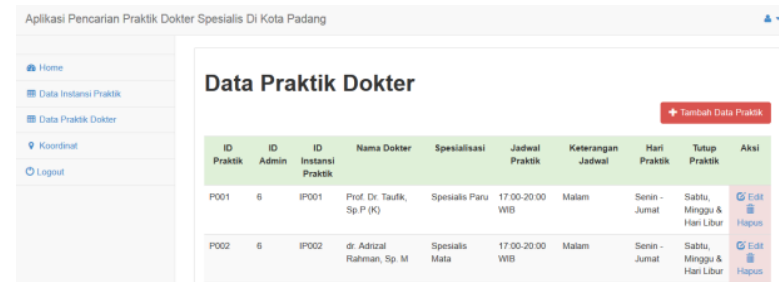

Gambar 13. Antarmuka Data Praktik Dokter

Admin web juga bisa memasukkan data koordinat lokasi praktik dokter. Koordinat lokasi berupa latitude dan longitude praktik dokter yang didapatkan dari link yang disediakan pada menu koordinat. Berikut tampilan user interface menu koordinat yang dapat dilihat pada Gambar 14 berikut :

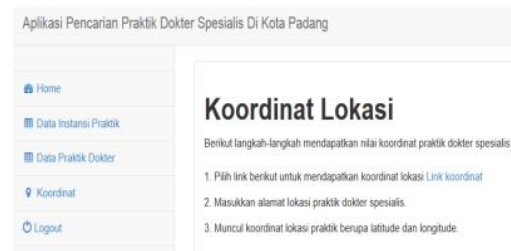

Gambar 14. Antarmuka Menu Koordinat Lokasi

Untuk mendapatkan latitude dan longitude tersebut, admin diminta untuk memilih link koordinat. Hasil dari link koordinat tersebut dapat dilihat pada Gambar 15 berikut :

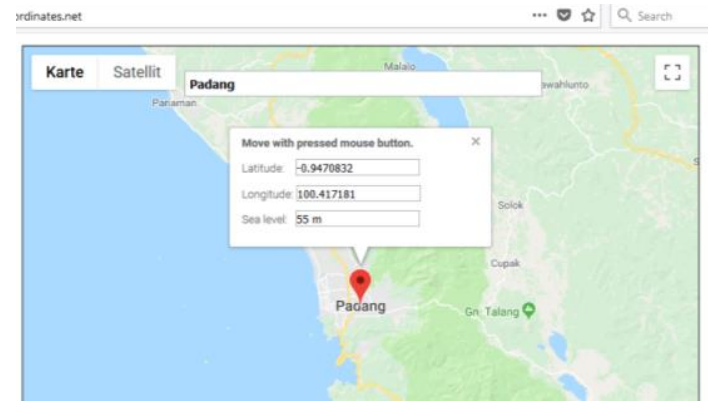

Gambar 15. Tampilan Link Koordinat Praktik Dokter

\section{KESIMPULAN}

Penelitian ini telah berhasil mengembangkan sebuah sistem yang bisa menyajikan informasi praktik dan spesialisasi dokter yang berada di Kota Padang. Selain itu sistem juga menemukan lokasi dokter terdekat sesuai dengan spesifikasi yang diinginkan. Sistem dibangun dari dua sisi yakni sisi client maupun sisi server. Sisi client sistem ini berjalan dengan baik di smartphone dengan operasi sistem minimum Android 5.0. Sistem ini sudah teruji dan dapat menyelesaikan masalah pencarian lokasi dan informasi praktik dokter yang berada di Kota Padang. Sistem ini perlu pengembangan dan pengujian lebih lanjut untuk menghasilkan sistem yang lebih baik dan cakupannya lebih luas. 


\section{REFERENCES}

[1] http://bppsdmk.kemkes.go.id/

[2] https://www.statista.com/

[3] Saadi, O., et al, "Application of remote sensing data and geographic information system for identifying potential areas of groundwater storage in middle Mouloya Basin of Morocco," Groundwater of Suistainable Development vol 14, 2021

[4] C. Jatmoko, E. Sugiarto, and S. Astuti, "Sistem Pemantau Pertumbuhan Pohon di Area Hutan Penampung Air Tanah Menggunakan Metode Penginderaan Jauh (INDERAJA) dan Sistem Informasi Geografis (SIG) di Wilayah Provinsi Jawa Tengah," Techno, vol. 14, no. 1, pp. 55-61, 2015.

[5] G. W. Sasmito, "Penerapan Metode Waterfall Pada Desain Sistem Informasi Geografis Industri Kabupaten Tegal,’ J. Inform. Pengemb. IT, vol. 2, no. 1, pp. 6-12, 2017.

[6] Virrantaus, K., Markkula, J., Garmash, A., Terziyan, Y.V., "Developing GIS-Supported LocationBased Services”. In: Proc. of WGIS'2001 - First International Workshop on Web Geographical Information Systems., Kyoto, Japan., pp 423-432. 2001.

[7] Gusman,T.,Sonatha,Y.,Azmi,M, "Pengembangan Aplikasi Informasi Pencarian Sekolah Berbasis Android di Kota Padang”, Jurnal Resti vol 2

\section{no 3, pp 597-60, 2018.}

[8] Esa Firmansyah, "Pemanfaatan Global Positioning System (GPS) Untuk Menghitung Luas Tanah ”, infomans, vol. 10, no. 1, pp. 16-33, May 2016.

[9] Perkasa,P, "Penggunaan Global Positioning System(GPS) untuk Dasar Survey pada Manusia", Jurnal Pendidikan dan Kejuruan BALANGA, vol 7 no 1, pp 22-33. 2019

[10] Masykur, F., “Implementasi Sistem Informasi Geografis Menggunakan Google Maps API Dalam Pemetaan Asal Mahasiswa,” J. SIMETRIS, vol. 5, no. 2, 2014.

[11] Pressman, R. Software Engineering A Practitioner's Approach Seventh Edition, Mc Graw Hill. 2010

[12] Rastogi,V. Software Development Life Cycle Models - Comparison, Consequences", International Journal of Computer Science and Information Technologies vol 6 No 1, 168-172. 2015

[13] Azmi,M., et al, "Pemanfaatan Metode Location Based Service dalam Pemetaan Fasilitas Kesehatan di Kota Padang”, Jurnal Ilmiah Matrik vol 22 No 2, 131-138. 2020

[14] Faiqunisa., Pratama, G. A. "Monitoring Aktivitas Keluarga Berbasis GPS Tracking". Jurnal Teknologi Informasi dan Komunikasi, 5(1), 2-3. 2016

[15] Safaat, Nazruddin H. Android Pemrograman Apliaksi Mobile Smartpjone dan Tablet PC Berbasis Android. Bandung: Informatika Bandung. 2014 